Pure Appl. Chem., Vol. 75, No. 10, pp. 1417-1432, 2003.

(C) 2003 IUPAC

\title{
Novel chemistry of indole in the synthesis of heterocycles ${ }^{\star}, \ddagger$
}

\author{
Gordon W. Gribble \\ Department of Chemistry, Dartmouth College, Hanover, NH 03755, USA
}

\begin{abstract}
Indoles that are substituted at the 2- or 3-position with electron-withdrawing groups (nitro, phenylsulfonyl) undergo nucleophilic addition, 1,3-dipolar cycloaddition, and Diels-Alder reactions to give a variety of indoles, pyrroloindoles, and carbazoles. New methods for the synthesis of furo[3,4- $b]$ indoles and the novel ring system furo[3,4-b]pyrrole are described for the first time. Diels-Alder reactions of furo[3,4- $b]$ pyrroles afford indoles after dehydration of the primary cycloadducts. Efficient syntheses of both 2- and 3-nitroindoles from indole are reported, and the first generation and successful electrophilic trapping of a 2,3-dilithioindole has been achieved.
\end{abstract}

\section{INTRODUCTION}

Although the chemistry of indole (1) has been investigated for more than 100 years, as summarized in Scheme 1 [1], recent times have seen the development of new indole chemistry, such as lithiated indoles and indole radicals for use in synthesis [2,3].

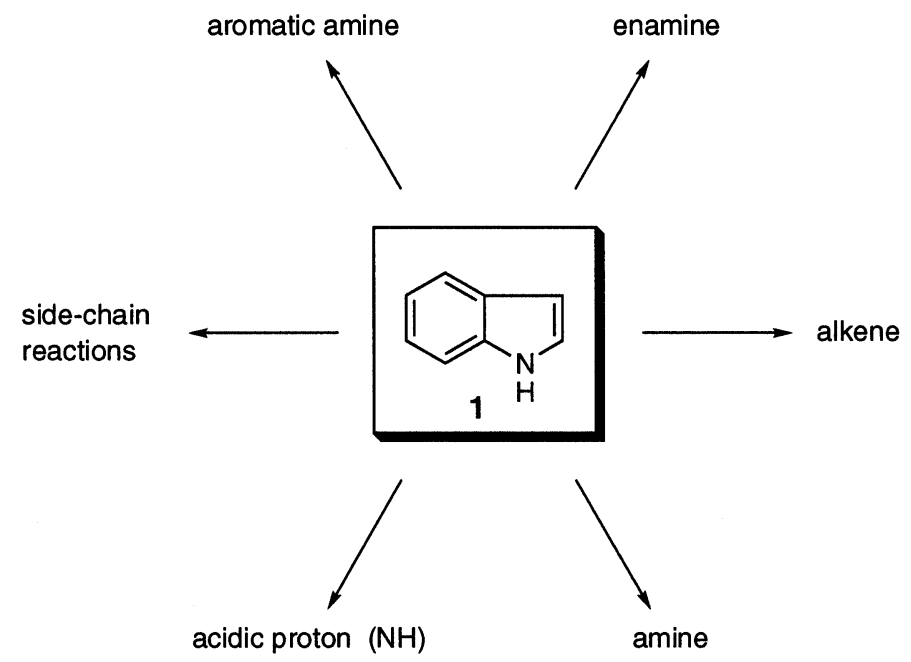

\section{Scheme 1}

In continuation of our own inveterate interest in the chemistry of indoles [4-6], we have begun to examine the chemistry of indoles that are substituted at the 2- or 3-position with a strong electronwithdrawing group (i.e., nitro, phenylsulfonyl, cyano), and also to generate and trap with electrophiles

*Lecture presented at the $4^{\text {th }}$ Florida Heterocyclic Conference, Gainesville, FL, USA, 10-12 March 2003. Other presentations are published in this issue, pp. 1403-1475.

${ }^{\ddagger}$ This paper is dedicated to Prof. Lloyd J. Dolby, who introduced the author to the wonders of indole chemistry in 1963. 
2,3-dilithioindoles (Scheme 2). One important application of our work is the development of simple and efficient syntheses of fused ring systems, such as pyrrolo[3,4-b]indoles, pyrrolo[2,3- $b]$ indoles, furo[3,4- $b]$ indoles, furo[3,4- $b]$ pyrroles, benzo[b]furo[2,3-c]pyrroles, and benzo[b]thieno[2,3-c]pyrroles, some of which can serve as synthetic analogs of indole-2,3-quinodimethane.

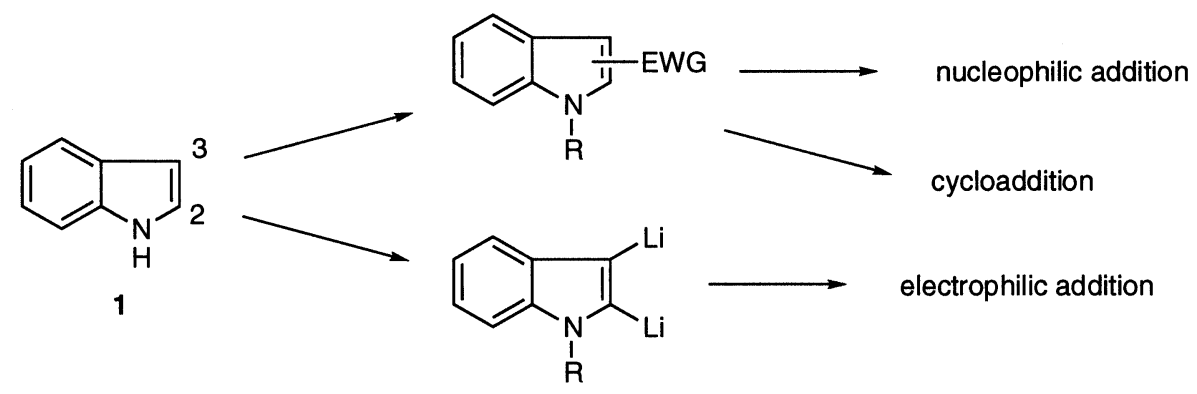

Scheme 2

\section{GENERATION AND CHEMISTRY OF 2,3-DILITHIOINDOLES}

Several years ago, we attempted to generate and trap 2,3-dilithio-1-(phenylsulfonyl)indole (4) with electrophiles to give 2,3-disubstituted indoles $\mathbf{8}$. Unfortunately, although we could synthesize 2,3-diiodoindole 3 in very good yield from indole (1), via 3-iodoindole 2 [7], bis-halogen lithium exchange of $\mathbf{3}$ to generate $\mathbf{4}$ and subsequent addition of electrophiles gave mainly the products of indole ring fragmentation, i.e., $\mathbf{6}$ and 7 (Scheme 3) [8]. This ring-opening path to 5 is presumably due not only to C-2,C-3 anionic repulsion, but also to the formation of stabilized phenylsulfonamide and phenylacetylide anions.<smiles>c1ccc2[nH]ccc2c1</smiles>

1<smiles>O=S(=O)(Oc1ccccc1)n1cc(I)c2ccccc21</smiles>

2

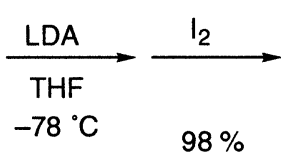

$98 \%$<smiles>O=S(=O)(c1ccccc1)n1c(I)c(I)c2ccccc21</smiles>

3<smiles>[CH-]</smiles>

$E^{+}$

?<smiles>I[13IH]</smiles><smiles>O=S(=O)(c1ccccc1)n1c(F)c(F)c2ccccc21</smiles>
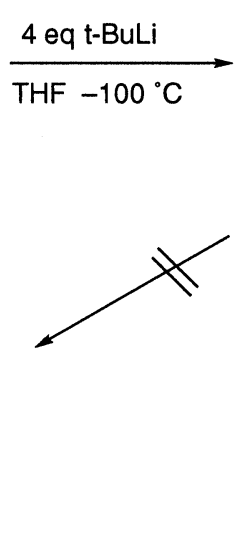<smiles></smiles>

6<smiles>O=S(=O)(c1ccccc1)N(Cl)c1ccccc1C#CCl</smiles><smiles>CCOC(=O)CCC(C)(C)[O+]</smiles><smiles>CCOC(=O)CON(C(=O)OCC)c1ccccc1C#Cc1ccccc1</smiles>

7

Scheme 3 
We reasoned that an $N$-substituted electron-donating or neutral group would mitigate this $\mathbf{4} \rightarrow \mathbf{5}$ ring fragmentation. Indeed, the readily synthesized 2,3-diiodo-1-methylindole (9) undergoes halogenmetal exchange with tert-butyllithium to give the relatively stable 2,3-dilithio-1-methylindole (10) (Scheme 4) [9]. Interestingly, diiodoindole 9 is converted to $N$-methylisatin (11) in excellent yield upon treatment with ruthenium [10]. Treatment of dilithioindole $\mathbf{1 0}$ with several electrophiles affords the expected 2,3-disubstituted products 12-16 (Scheme 4) [9].<smiles>c1ccc2c(c1)CCCN2</smiles>

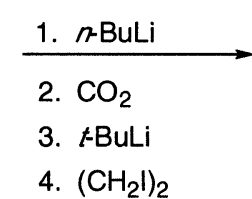<smiles>Ic1cc2ccccc2[nH]1</smiles>

1. $\mathrm{KOH}, \mathrm{I}_{2}$<smiles>Cc1ccc(S(=O)(=O)O)cc1</smiles><smiles>Cn1c(I)c(I)c2ccccc21</smiles>

1

4. $\left(\mathrm{CH}_{2}\right)_{2}$

$90 \%$<smiles>CS(=O)(=O)N1C(=O)C(=O)c2ccccc21</smiles>

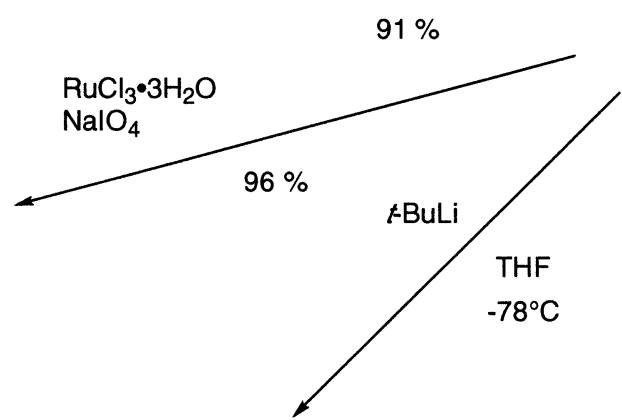

9

11<smiles>Cn1ccc2ccccc21</smiles>

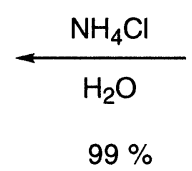

12<smiles>[N+]n1c(Cl)c(Cl)c2ccccc21</smiles>

10

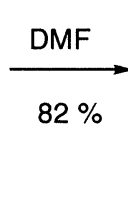

$82 \%$<smiles>Cn1c(C=O)c(C=O)c2ccccc21</smiles>

16<smiles>Cn1c(C(=O)O)c(C(=O)O)c2ccccc21</smiles>

13<smiles>CC(=O)c1c(C(C)=O)n(C)c2ccccc12</smiles>

\section{Scheme 4}

14

Although we have been unable to effect selective mono-halogen metal exchange on 2,3-diiodo-1methylindole (9), we have successfully accomplished such chemistry with 2,3-dibromo-1-methylindole (17), which is prepared in $92 \%$ yield from indole (Scheme 5) [11]. Thus, selective conversion of $\mathbf{1 7}$ to 3-bromo-2-lithio-1-methylindole (18) and subsequent trapping with electrophiles gives the corresponding 3-bromo-2-substituted indoles (Scheme 5). 
<smiles>c1ccc2[nH]ccc2c1</smiles>

1. $n$ BuLi 2. $\mathrm{CO}_{2}$

3. $t \mathrm{BuLi}$

4. $\mathrm{BrCl}_{2} \mathrm{CCCl}_{2} \mathrm{Br}$<smiles>Brc1cc2ccccc2[nH]1</smiles>

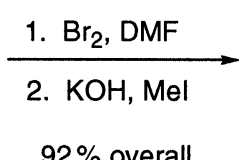

$92 \%$ overall

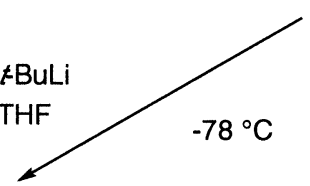<smiles>Cn1c(Br)c(Br)c2ccccc21</smiles>

17<smiles>Cn1c(C(=O)O)c(Br)c2ccccc21</smiles><smiles>CC(=O)[13C](=O)[O-]</smiles><smiles>Cn1c(Cl)c(Br)c2ccccc21</smiles><smiles>CC(C)[Mg]Cl</smiles><smiles>Cn1cc(Br)c2ccccc21</smiles>

18<smiles>C[18OH]</smiles><smiles>Cn1c(C=O)c(Br)c2ccccc21</smiles>

\section{Scheme 5}

Furthermore, we have found in a one-pot operation that both bromines of $\mathbf{1 7}$ can be sequentially replaced by electrophiles to give indoles $\mathbf{1 9}$ and $\mathbf{2 0}$ (Scheme 6) [11]. Subsequent bromination of 17, depending on the conditions, affords the naturally occurring 2,3,6-tribromo-1-methylindole and 2,3,5,6-tetrabromo-1-methylindole (not shown) [12].<smiles>Cc1c(C=O)c2ccccc2n1C</smiles>

19<smiles>Cn1c(Br)c(Br)c2ccccc21</smiles>

$88 \%$

17

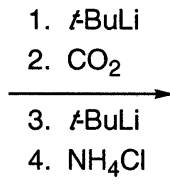

$95 \%$<smiles>Cn1c(C(=O)O)cc2ccccc21</smiles>

20

Scheme 6

\section{SYNTHESIS OF 2- AND 3-NITROINDOLES}

Because the nitro group is a very powerful electron-withdrawing group, this was our first choice with which to investigate the chemistry of electron-deficient indoles. Although 3-nitroindole can be prepared by direct nitration of indole, the yield is low [13]. Alternatively, we have found that the C-3 nitration of $\mathrm{N}$-protected indoles is a very efficient method to access 3-nitroindoles (Scheme 7) [14] and is far superior to direct nitration of indole itself. Low temperature is necessary to minimize the formation of 6-nitroindoles. Under these conditions, 3-nitro-1-(phenylsulfonyl)indole (22) is now readily available. 
<smiles>O=S(=O)(c1ccccc1)n1ccc2ccccc21</smiles>

21

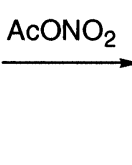

$25^{\circ} \mathrm{C}(82 \%)$

$-10^{\circ} \mathrm{C}(78 \%)$

$-50^{\circ} \mathrm{C}(75 \%)$

$-60^{\circ} \mathrm{C}(83 \%)$<smiles>O=[N+]([O-])c1cn(S(=O)(=O)c2ccccc2)c2ccccc12</smiles>

22<smiles>O=[N+]([O-])c1ccc2ccn(S(=O)(=O)c3ccccc3)c2c1</smiles>

18
11
5
2

Scheme 7<smiles>[R]n1ccc2ccccc21</smiles><smiles>[H][R]O[N+](=O)[O-]</smiles><smiles>[R]n1cc([N+](=O)[O-])c2ccccc21</smiles>

$$
\begin{aligned}
& \mathrm{R}=\mathrm{CO}_{2} \mathrm{Et}(62 \%) \\
& \mathrm{R}=\mathrm{CH}_{2} \mathrm{Ph} \quad(50 \%) \\
& \mathrm{R}=\mathrm{CH}_{3} \quad(41 \%) \\
& \mathrm{R}=\mathrm{Ph}(75 \%) \\
& \mathrm{R}=\mathrm{COCH}_{3}(48 \%) \\
& \mathrm{R}=\mathrm{CO}_{2} \mathrm{Bu}(62 \%) \\
& \mathrm{R}=\mathrm{CO}_{2} / \mathrm{Bu}(66 \%) \\
& \mathrm{R}=2-\operatorname{pyr}(50 \%)\left(0^{\circ} \mathrm{C}\right)
\end{aligned}
$$

When we began our work, 2-nitroindole (24) was unknown. Our initial synthesis of $\mathbf{2 4}$ utilized the reliable Sundberg indole synthesis starting from 2-nitrobenzaldehyde (Scheme 8) [15].
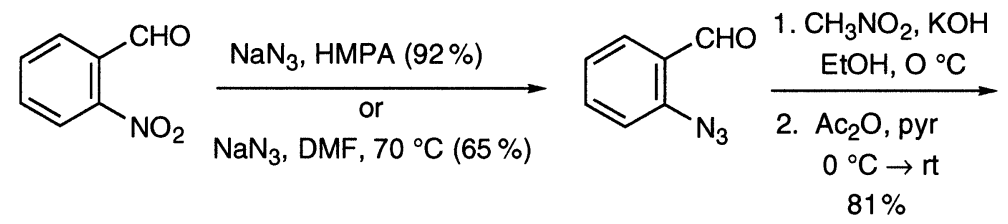<smiles>[N-]=[N+]([O-])C=Cc1ccccc1[N+](=O)[O-]</smiles>

23

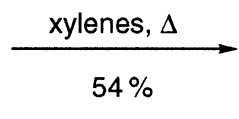

1. $\mathrm{NaH}, \mathrm{DMF}, 0^{\circ} \mathrm{C}$ 2. $\mathrm{PhSO}_{2} \mathrm{C}$

$57 \%$<smiles>O=[N+]([O-])c1cc2ccccc2[nH]1</smiles>

24

\section{Scheme 8}<smiles>O=[N+]([O-])c1cc2ccccc2n1S(=O)(=O)c1ccccc1</smiles>

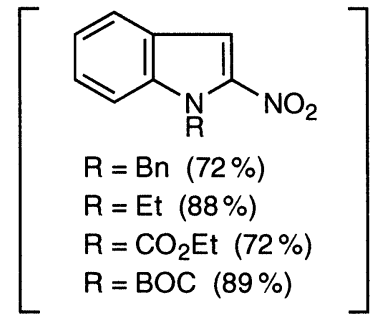

Unfortunately, the intermediate 2-azidonitrostyrene $\mathbf{2 3}$ is a potent skin and eye irritant, not unlike "pepper spray" ("CS", $o$-chlorobenzalmalonitrile), and, as a result, we needed to find an alternative synthesis of 2-nitroindoles. Our earlier work with 2-lithioindoles [7,16] suggested that direct nitration of this species would afford 2-nitroindoles. After considerable experimentation with different sources of " $\mathrm{NO}_{2}{ }^{+}$" (nitronium triflate, nitronium boron tetrafluoride, acetyl nitrate, pivaloyl nitrate), we found that adding dinitrogen tetroxide onto a frozen THF reaction mixture [17] of a 2-lithioindole gives the corresponding 2-nitroindole in reasonable yields (Scheme 9) [18]. Deprotection of the $N$-Boc-2-nitroindoles affords the parent 2-nitroindoles. 
<smiles>[R]c1cn(S(=O)(=O)c2ccccc2)c2ccccc12</smiles>

1. $t$ BuLi, THF, $-78^{\circ} \mathrm{C}$

2. $\mathrm{N}_{2} \mathrm{O}_{4}, \mathrm{THF},-120^{\circ} \mathrm{C}$ to $\mathrm{r}$<smiles>[R]c1c([N+](=O)[O-])n(S(=O)(=O)O)c2ccccc12</smiles>

$\mathrm{R}=\mathrm{H}, 67 \%$

$\mathrm{R}=\mathrm{Me}, 63 \%$<smiles>[R]c1cn(C(=O)OCc2ccccc2)c2ccccc12</smiles>
2. $\mathrm{N}_{2} \mathrm{O}_{4}$

$$
\begin{aligned}
& R=H, 78 \% \\
& R=M e, 74 \%
\end{aligned}
$$<smiles>[R]c1c([N+](=O)[O-])n(C(=O)OCc2ccccc2)c2ccccc12</smiles><smiles>[R]c1c([N+](=O)[O-])[nH]c2ccccc12</smiles>

$\mathrm{R}=\mathrm{H}, 98 \%$ $\mathrm{R}=\mathrm{Me}, 100 \%$

Scheme 9

\section{NUCLEOPHILIC ADDITION REACTIONS}

Although electrophilic additions to C-3 of indole are well established [1,2], nucleophilic addition reactions to the indole double bond are less well known [19]. Our initial work in this area involved 1,2-bis(phenylsulfonyl)indole (25), and we found that this compound undergoes smooth addition of lithium dialkylcuprates to yield the corresponding 3-alkyl-2-(phenylsulfonyl)indoles devoid of the $N$-phenylsulfonyl group (Scheme 10) $[15,20,21]$. Furthermore, we were able to intercept the presumed intermediate C-2 anion with methyl iodide to give 2,3-dimethyl-1-(phenylsulfonyl)indole (26) in $70 \%$ yield. Independent synthesis or conversion to known compounds confirmed the structures of these cuprate addition products.

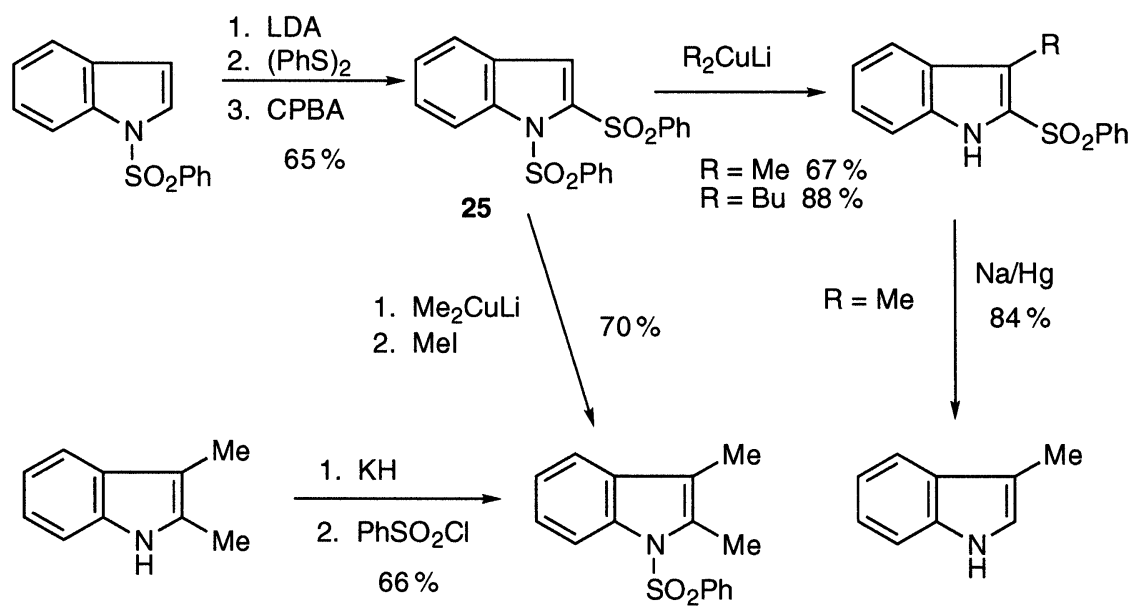

\section{Scheme 10}

Similarly, nucleophilic addition reactions of 2-nitro-1-(phenylsulfonyl)indole (27) result in the expulsion of the $\mathrm{N}$-phenylsulfonyl group to give the corresponding 3-substituted 2-nitroindoles (Scheme 11) [20]. A minor product in the reaction of $\mathbf{2 7}$ with indole anion results from attack at C-3 to give a 3,3'-biindole. 


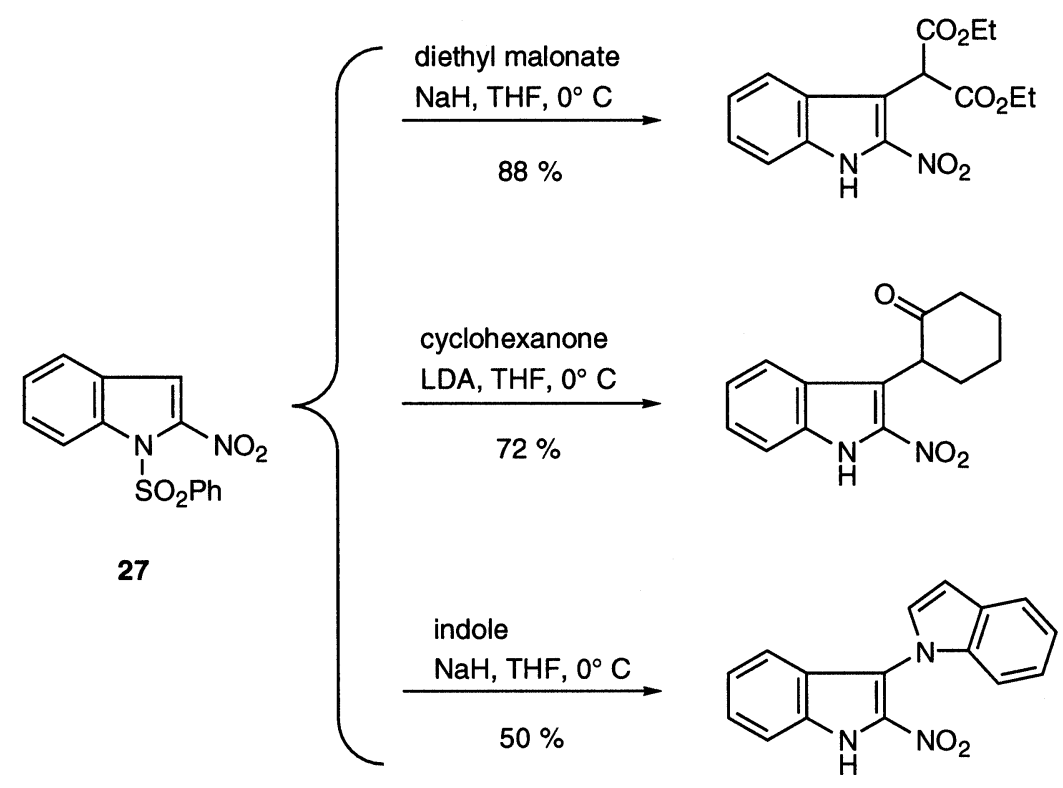

\section{Scheme 11}

In contrast to the behavior of 27, 1-carboethoxy-2-nitroindole (28) reacts with the anion of diethyl malonate to give diester $\mathbf{2 9}$ with retention of the $N$-carboethoxy group and formal loss of nitrous acid (Scheme 12) [21]. Diester 29 was converted to the known ethyl 3-indoleacetate using a Krapcho decarboethoxylation.<smiles>CCOC(=O)n1c([N+](=O)[O-])cc2ccccc21</smiles>

28<smiles>CCCC(C(=O)OCC)c1cn(CC(=O)OCC)c2ccccc12</smiles>

29<smiles>CCOC(=O)Cc1c[nH]c2ccccc12</smiles>

\section{Scheme 12}

Nucleophilic additions to 3-nitro-1-(phenylsulfonyl)indole (22) take a different course and result in trans-dihydroindole products (Scheme 13) [21]. 


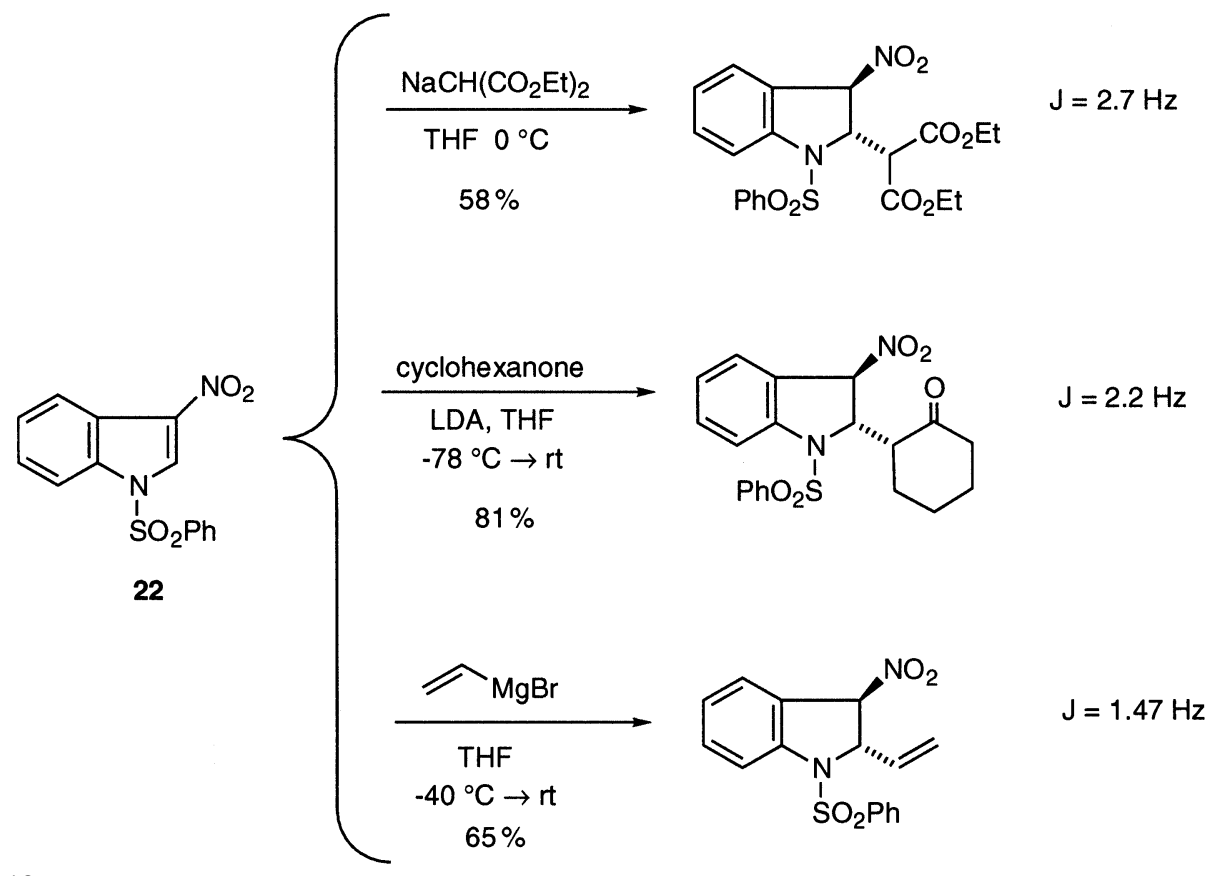

\section{Scheme 13}

A similar path is observed with nucleophilic additions to 1-Boc-3-nitroindole, but alkyl Grignards add to $\mathbf{2 2}$ to afford significant amounts of 2-alkylindoxyls 30, the products of a formal Nef reaction, in addition to the trans-2-alkyl-3-nitroindolines, which are the major products (Scheme 14) [21]. Both 2-lithiopyridine and 2-lithiothiazole add to 22 to give the corresponding 2-heteroaryl-3-nitroindoles, following loss of phenylsulfinate.<smiles>CCc1c([N+](=O)[O-])c2ccccc2n1-c1ccccc1</smiles>
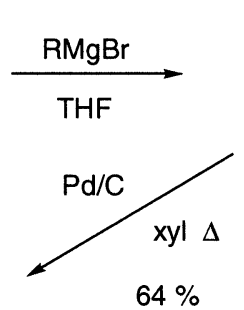<smiles>O=[N+]([O-])C1c2ccccc2N(S(=O)(=O)c2ccccc2)C1P</smiles>

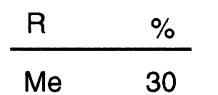

Et $\quad 41$ iPr<smiles>O=C1c2ccccc2N(S(=O)(=O)c2ccccc2)C1P</smiles>

30

\section{Scheme 14}

\section{INDOLE-2,3-QUINODIMETHANE ANALOGS}

A major interest in our indole research program has been to synthesize furo[3,4- $b$ ]indoles (31) and pyrrolo[3,4- $b$ ]indoles (32) as indole-2,3-quinodimethane (33) analogs, since the latter species is unstable and has never been isolated. Furthermore, fused heterocycles $\mathbf{3 1}$ and $\mathbf{3 2}$ can be modified prior to subsequent chemistry (Scheme 15). 
<smiles>c1ccc2[nH]ccc2c1</smiles>

1

Metalation

and further chemistry
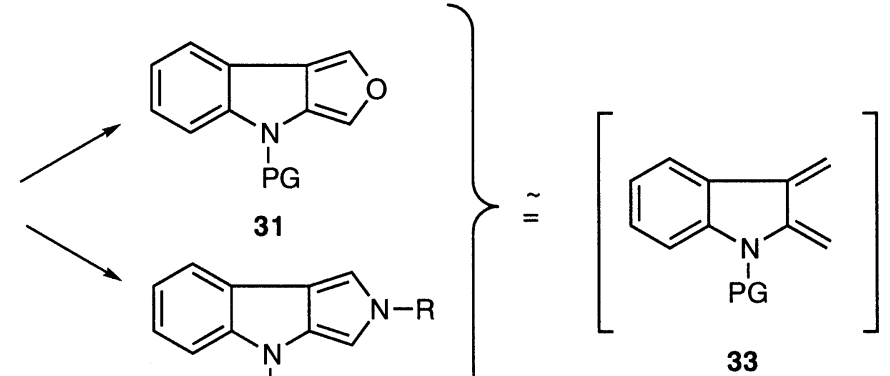

33

32

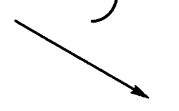

Cycloaddition reactions

Scheme 15

\section{Pyrrolo[3,4-b]indoles}

Although pyrroloindoles 32 are well known, multistep pathways are usually involved in the synthesis of this ring system [22,23]. It seemed that a possible one-step route to these pyrroloindoles would be the Barton-Zard pyrrole synthesis involving the reaction between nitroalkenes and the anion of isocyanoacetate [24,25]. Much to our surprise, the reaction of 3-nitro-1-(phenylsulfonyl)indole (22) under Barton-Zard conditions gave the rearranged pyrrolo[2,3- $b$ ]indole $\mathbf{3 5}$ instead of the expected pyrrolo[3,4-b]indole 34 (Scheme 16) [26]. A possible pathway for this unexpected result is shown.<smiles>O=[N+]([O-])c1cn(S(=O)(=O)c2ccccc2)c2ccccc12</smiles>

22

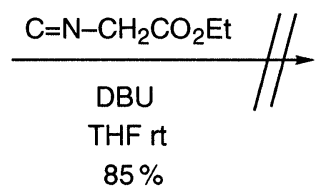

$85 \%$<smiles>CCOC(=O)c1[nH]cc2c3ccccc3n(S(=O)(=O)O)c12</smiles>

34

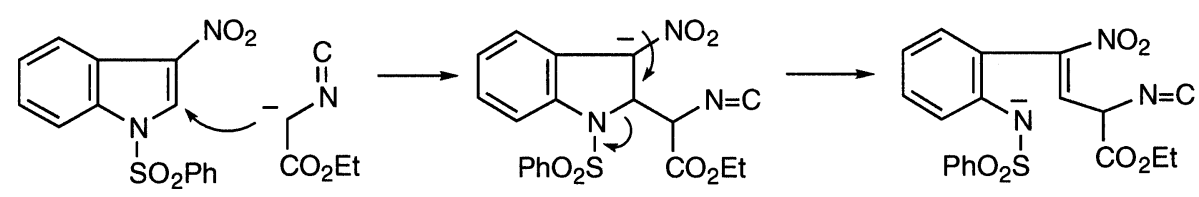

22<smiles>CCOC(=O)C1=NC(c2ccccc2NS(=O)(=O)O)C=C1[N+](=O)[O-]</smiles>

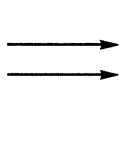

Scheme 16<smiles>CCOC(=O)c1cc2c3ccccc3n(S(=O)(=O)O)c2[nH]1</smiles>

35

The structures of both $\mathbf{3 4}$ and $\mathbf{3 5}$ were confirmed by independent synthesis (Schemes 17 and 18). 
<smiles>Cc1cn(S(=O)(=O)c2ccccc2)c2ccccc12</smiles><smiles>CCOC(=O)C(=O)Cl</smiles>
$31 \%$<smiles>CCOC(=O)c1c(CBr)c2ccccc2n1S(=O)(=O)O</smiles>

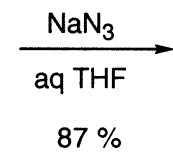<smiles></smiles><smiles>O=[W]OCc1ccccc1</smiles><smiles>CCOC(=O)c1[nH]cc2c3ccccc3n(S(=O)(=O)c3ccccc3)c12</smiles>

34

Scheme 17<smiles>O=S(=O)(c1ccccc1)n1cc(C=Cc2ccccc2)c2ccccc21</smiles>

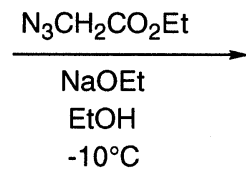

$30 \%$<smiles>CCOC(=O)c1cc2c3ccccc3n(S(=O)(=O)O)c2[nH]1</smiles>

35

\section{Scheme 18}<smiles>CCOC(=Cc1cn(S(=O)(=O)c2ccccc2)c2ccccc12)C(C)(C)[Mg]</smiles>

$43 \%$

Similar to what we saw earlier, a switch to a less electron-withdrawing $N$-protecting group changes the course of this reaction and prevents this abnormal Barton-Zard pathway, involving indole ring opening, and now affords the "normal" pyrrolo[3,4-b]indoles 36 and $\mathbf{3 7}$ (Scheme 19) [27].<smiles>CCOC(=O)n1cc([N+](=O)[O-])c2ccccc21</smiles><smiles>O=[N+]([O-])c1cn(Cc2ccccc2)c2ccccc12</smiles>

Scheme 19

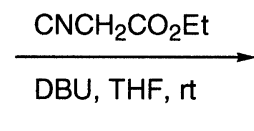

$91 \%$

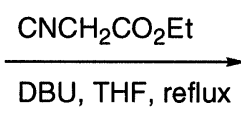

$60 \%$<smiles>CCOCn1c2ccccc2c2c[nH]c(C(=O)OCC)c21</smiles><smiles>CCOC(=O)c1[nH]cc2c3ccccc3n(Cc3ccccc3)c12</smiles>

37 
Our earlier work with munchnone cycloaddition reactions [28] suggested that these mesoionic 1,3-dipoles could also react with electron-deficient indoles to afford pyrrolo[3,4- $b]$ indoles in one operation. Indeed, this has proven to be the case. Both 2- and 3-nitro-1-(phenylsulfonyl)indoles (27 and 22) react with munchnone 38, which is generated in situ by cyclodehydration of the appropriate $N$-acyl amino acid with 1,3-diisopropylcarbodiimide (DIPC), to give pyrroloindole 39 in very good yields (Scheme 20) [29].

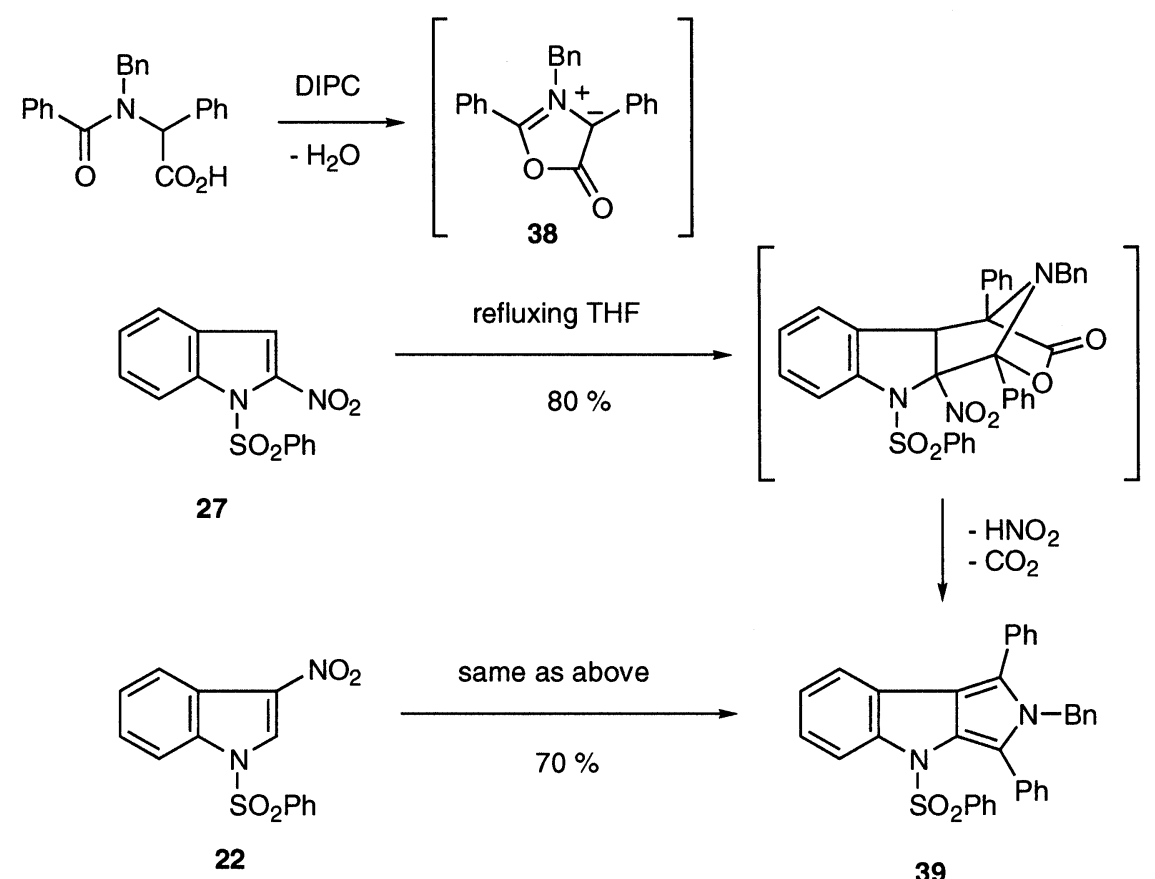

Scheme 20

The corresponding 1,3-dimethylpyrroloindoles can be crafted in similar fashion (Scheme 21) [29].

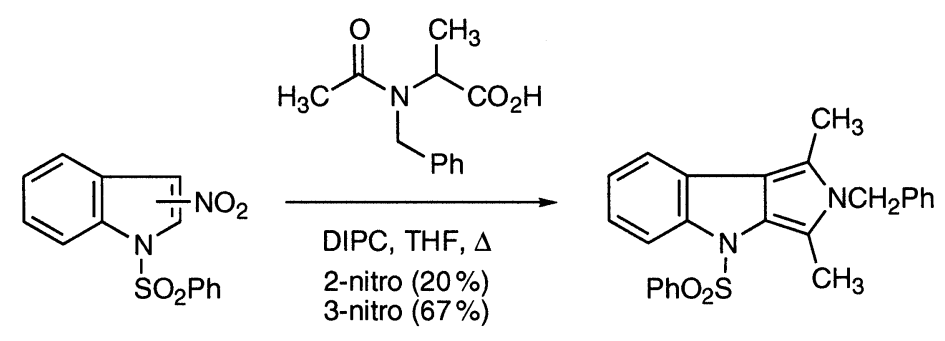

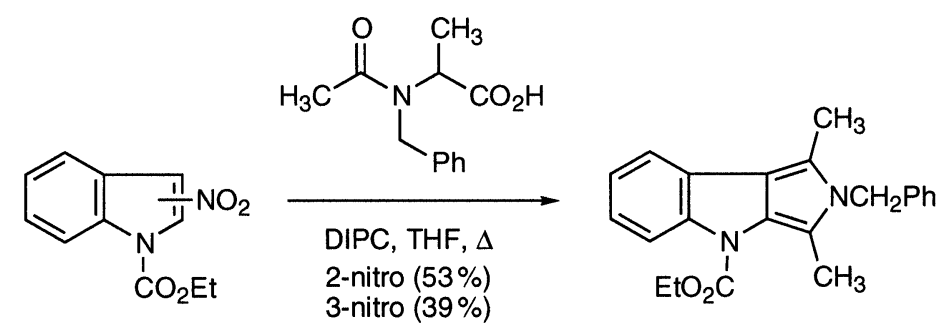

Scheme 21 
Interestingly, the unsymmetrical munchnones $\mathbf{4 0}$ and $\mathbf{4 1}$ generally display anti-FMO regioselectivity in cycloaddition reactions with both 3- and 2-nitroindoles (Scheme 22) [30]. The isomeric pyrroloindoles were separated by chromatography and characterized by NMR (NOE), X-ray crystal structure determination [31], and/or independent synthesis.

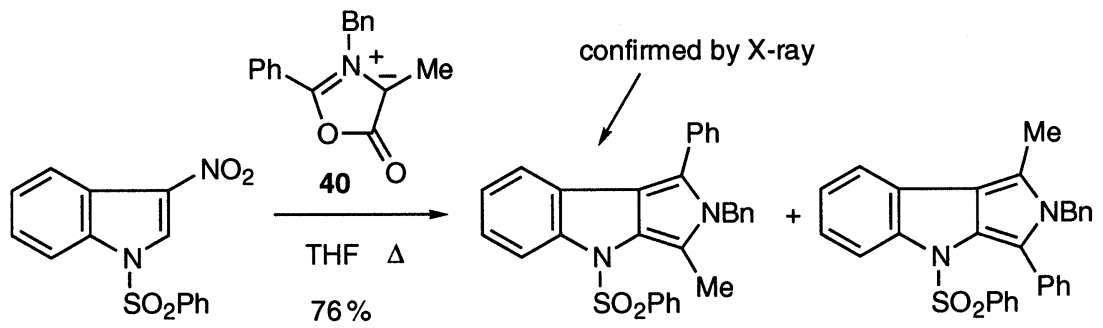

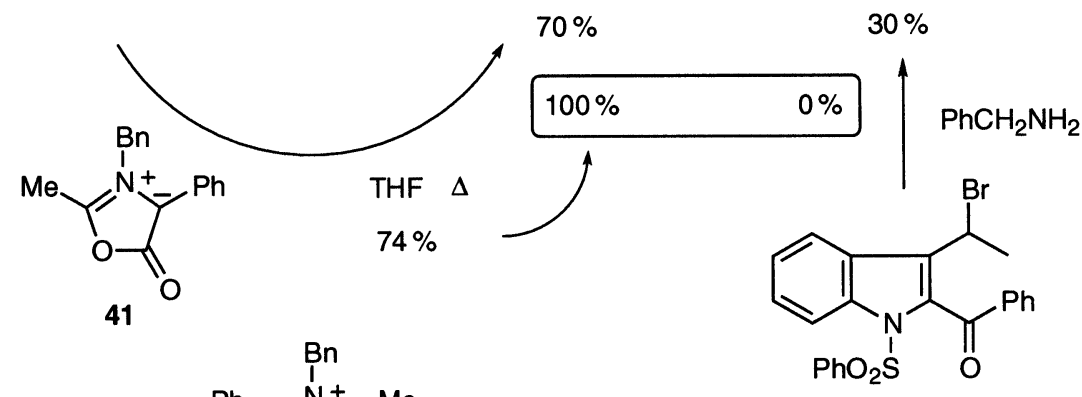<smiles>CCOC(=O)c1c(C=C2C(=O)C(=O)[N+](Cc3ccccc3)=C2c2ccccc2)oc([N+](=O)[O-])c1C</smiles>

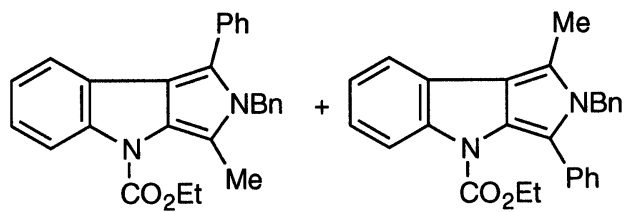<smiles></smiles>

$90 \%$

$10 \%$

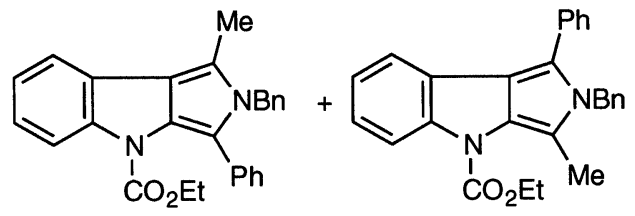

\section{Scheme 22}

$90 \%$

$10 \%$

Both 2-nitrobenzofuran and 3-nitrobenzothiophene undergo similar reactions with munchnones to give the novel fused heterocycles shown (Scheme 23) [29]. 


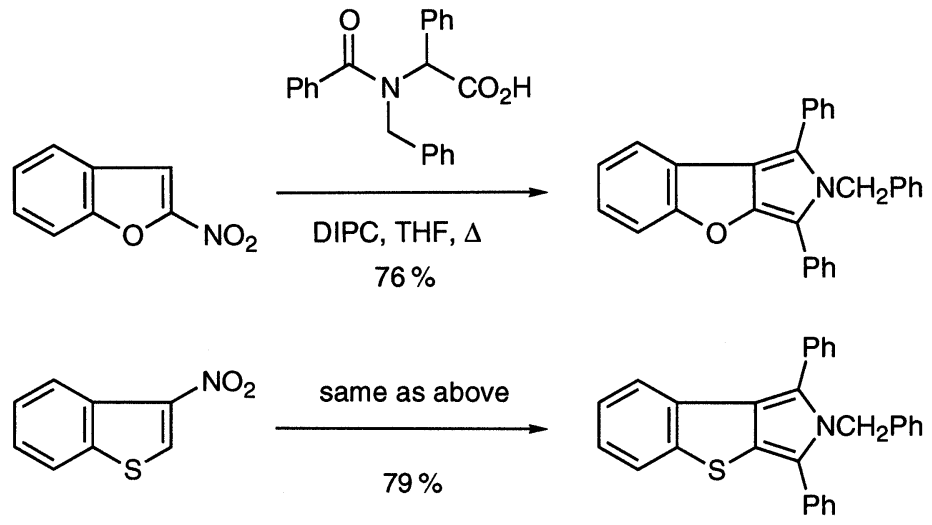

Scheme 23

\section{Furo[3,4-b]indoles}

The fused heterocycle $4 H$-furo[3,4- $b$ ]indole has played an important role in our research program for 20 years [32-37]. Nevertheless, the syntheses of this ring system typically involve several steps and, especially for the unsubstituted compound $\mathbf{4 3}$, are often erratic (Scheme 24).<smiles>c1ccc2[nH]ccc2c1</smiles><smiles>Cc1c[nH]c2ccccc12</smiles><smiles>c1ccc2[nH]ccc2c1</smiles>
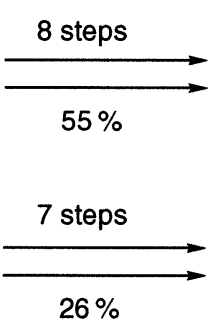

5 steps

$20-30 \%$<smiles>Cc1oc(C)c2c1c1ccccc1n2S(=O)(=O)O</smiles><smiles>Cc1occ2c1c1ccccc1n2S(=O)(=O)O</smiles><smiles>O=S(=O)(O)n1c2ccccc2c2cocc21</smiles>

43

\section{Scheme 24}

In view of the importance of furo[3,4- $b$ ]indoles as indole-2,3-quinodimethane analogs, we needed to develop shorter, more efficient routes to this ring system. Indeed, we have found that C-2 lithiation of acetal 44, subsequent quenching with an aldehyde, and acid-induced cyclization affords good to very good overall yields of furoindoles $\mathbf{4 5}$ (Scheme 25) [38]. 
<smiles>Cc1cn(-c2ccccc2)c2ccccc12</smiles><smiles>O=S(=O)(O)n1c(C(O)O)c(C2OCCO2)c2ccccc21</smiles><smiles>O=S(=O)(C1=C(C2OCCO2)c2ccccc21)c1ccccc1</smiles>

1. $s$ BuLi, THF, $-78^{\circ} \mathrm{C}$

44

$\mathrm{CH}_{2} \mathrm{Cl}_{2}$, TFA

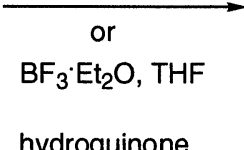<smiles>[R]c1occ2c3ccccc3n(S(=O)(=O)O)c12</smiles>

45

$$
\begin{aligned}
& \mathrm{R}=\mathrm{H} \quad(52 \%, 2 \text { steps }) \\
& \mathrm{R}=\mathrm{Me} \quad(52 \%, 2 \text { steps }) \\
& \mathrm{R}=\mathrm{Ph} \quad(70 \%, 2 \text { steps }) \\
& \mathrm{R}=n \text { Heptyl } \quad(61 \%, 2 \text { steps })
\end{aligned}
$$

\section{Scheme 25}

Slightly different tactics provide an efficient synthesis of the important 1,3-dimethylfuroindole $\mathbf{4 6}$ (Scheme 26) [39].
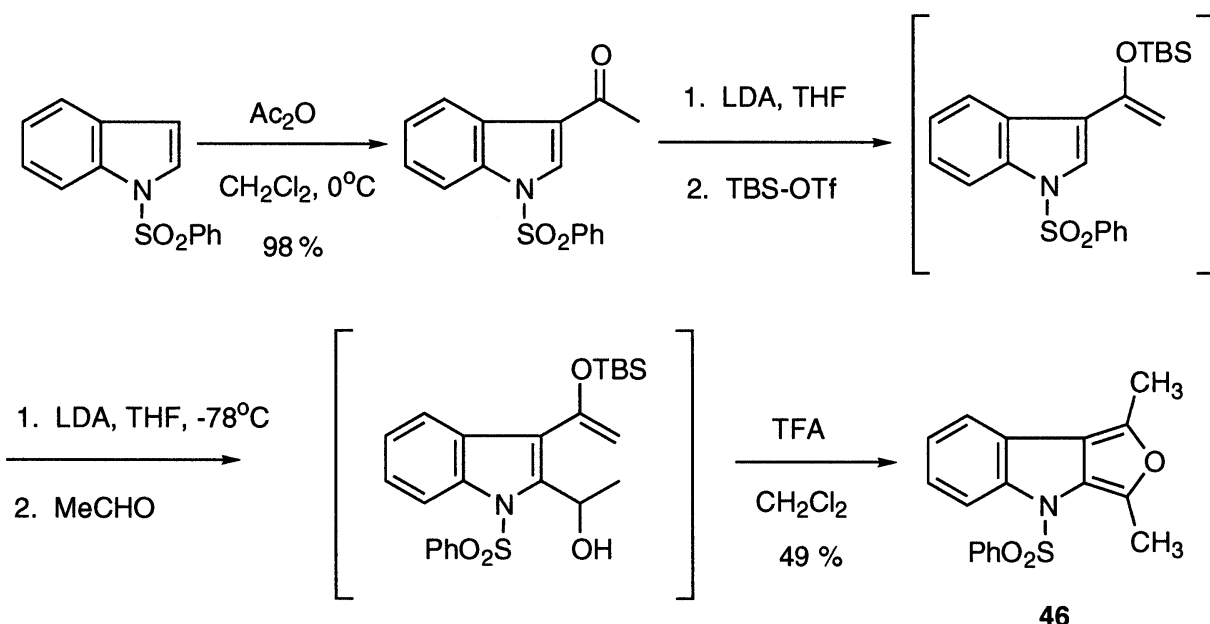

\section{Scheme 26}

This same strategy has afforded bis-furoindole 47 (Scheme 27) [21], a compound that we previously synthesized in very poor overall yield [34]. 
<smiles>c1ccc2[nH]ccc2c1</smiles>

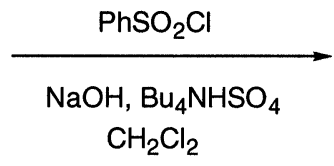

$94 \%$<smiles>O=C(CCCCCCCCCCC(=O)c1cn(S(=O)(=O)Oc2ccccc2)c2ccccc12)c1cn(S(=O)(=O)O)c2ccccc12</smiles><smiles>Cc1oc(CCCCCCCCCCc2oc(C)c3c2c2ccccc2n3S(=O)(=O)Oc2ccccc2)c2c3ccccc3n(S(=O)(=O)O)c12</smiles>

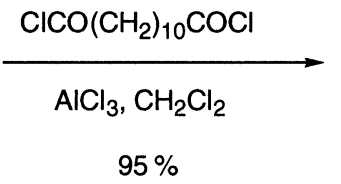

1. LDA, THF, $-78^{\circ} \mathrm{C}$

2. TBSOTf

3. LDA, THF

4. $\mathrm{MeCHO}$

5. TFA, $\mathrm{CH}_{2} \mathrm{Cl}_{2}$

$30 \%$

Scheme 27

\section{CONCLUSION}

Despite the intense scrutiny that indoles have undergone for the past 100 years, new chemistry of this fascinating heterocycle continues to be revealed. In particular, C-2 and C-3 electron-withdrawing substituents on the indole ring allow for a variety of nucleophilic addition and cycloaddition reactions to proceed, the course of which often depends on the $N$-protecting group. Space does not allow the presentation of our work involving Diels-Alder reactions with 2- and 3-nitroindoles leading to carbazoles [40] and the synthesis and Diels-Alder reactions of furo[3,4- $b$ ]pyrroles affording indoles [41].

\section{ACKNOWLEDGMENTS}

The author is grateful to his students, whose names appear in the references, for their hard work, creativity, and superb experimental skill, which made possible any success that we may have achieved in discovering new indole chemistry over the past 20 years.

\section{REFERENCES}

1. R. J. Sundberg. The Chemistry of Indoles, Academic Press, New York (1970).

2. R. J. Sundberg. Indoles, Academic Press, London (1996).

3. J. J. Li. In Alkaloids: Chemical and Biological Perspectives, S. W. Pelletier (Ed.), pp. 573-621, Pergamon Press, Amsterdam (2001).

4. L. J. Dolby and G. W. Gribble. J. Heterocycl. Chem. 3, 124-125 (1966).

5. L. J. Dolby and G. W. Gribble. J. Org. Chem. 32, 1391-1398 (1967).

6. L. J. Dolby and G. W. Gribble. Tetrahedron 24, 6377-6386 (1968).

7. M. G. Saulnier and G. W. Gribble. J. Org. Chem. 47, 757-761 (1982).

8. G. W. Gribble and M. G. Saulnier. J. Org. Chem. 48, 607--609 (1983).

9. Y. Liu and G. W. Gribble. Tetrahedron Lett. 42, 2949-2951 (2001).

10. G. W. Gribble and Y. Liu. Org. Prep. Proc. Int. 33, 615-619 (2001).

11. Y. Liu and G. W. Gribble. Tetrahedron Lett. 43, 7135-7137 (2002).

12. Y. Liu and G. W. Gribble. J. Nat. Prod. 65, 748-749 (2002).

13. G. Berti, A. Da Settimo, E. Nannipieri. J. Chem. Soc. (C) 2145-2151 (1968). 
14. E. T. Pelkey and G. W. Gribble. Synthesis 1117-1122 (1999).

15. E. T. Pelkey and G. W. Gribble. Tetrahedron Lett. 38, 5603-5606 (1997).

16. M. G. Saulnier and G. W. Gribble. J. Org. Chem. 47, 2810-2812 (1982).

17. K. Tani, K. Lukin, P. E. Eaton. J. Am. Chem. Soc. 119, 1476-1477 (1997).

18. J. Jiang and G. W. Gribble. Tetrahedron Lett. 43, 4115-4117 (2002).

19. J. A. Joule. Prog. Het. Chem. 11, 45-65 (1999).

20. E. T. Pelkey, T. C. Barden, G. W. Gribble. Tetrahedron Lett. 40, 7615-7619 (1999).

21. Unpublished results from our laboratory.

22. C.-K. Sha. Adv. Nitrogen Heterocycles 2, 147-178 (1996).

23. K. Daly, R. Nomak, J. K. Snyder. Tetrahedron Lett. 38, 8611-8614 (1997).

24. D. H. R. Barton and S. Z. Zard. J. Chem. Soc., Chem. Commun. 1098-1100 (1985).

25. D. H. R. Barton, J. Kervagoret, S. Z. Zard. Tetrahedron 46, 7587-7598 (1990).

26. E. T. Pelkey, L. Chang, G. W. Gribble. Chem. Commun. 1909-1910 (1996).

27. E. T. Pelkey and G. W. Gribble. Chem. Commun. 1873-1874 (1997).

28. G. W. Gribble, W. R. Sponholtz III, F. L. Switzer, F. J. D’Amato, M. P. Byrn. Chem. Commun. 993-994 (1997).

29. G. W. Gribble, E. T. Pelkey, F. L. Switzer. Synlett 1061-1062 (1998).

30. G. W. Gribble, E. T. Pelkey, W. M. Simon, H. A. Trujillo. Tetrahedron 56, 10133-10140 (2000).

31. W. M. Simon, H. A. Trujillo, E. T. Pelkey, G. W. Gribble, J. P. Jasinski. Acta Cryst. C56, 461-462 (2000).

32. M. G. Saulnier and G. W. Gribble. Tetrahedron Lett. 24, 5435-5438 (1983).

33. G. W. Gribble, M. G. Saulnier, M. P. Sibi, J. A. Obaza-Nutaitis. J. Org. Chem. 49, 4518-4523 (1984).

34. G. W. Gribble and M. G. Saulnier. J. Chem. Soc., Chem. Commun. 168-169 (1984).

35. D. A. Davis and G. W. Gribble. Tetrahedron Lett. 31, 1081-1084 (1990).

36. G. W. Gribble, D. J. Keavy, D. A. Davis, M. G. Saulnier, B. Pelcman, T. C. Barden, M. P. Sibi, E. R. Olson, J. J. BelBruno. J. Org. Chem. 57, 5878-5891 (1992).

37. G. W. Gribble, R. A. Silva, M. G. Saulnier. Synth. Commun. 29, 729-747 (1999).

38. G. W. Gribble, J. Jiang, Y. Liu. J. Org. Chem. 67, 1001-1003 (2002).

39. J. Jiang and G. W. Gribble. Org. Prep. Proc. Int. 34, 533-535 (2002).

40. T. L. S. Kishbaugh and G. W. Gribble. Tetrahedron Lett. 42, 4783-4785 (2001).

41. N. V. Moskalev and G. W. Gribble. Tetrahedron Lett. 43, 197-201 (2002). 